\title{
Factor Analysis with Health Belief Model on the Adherence To Methadone Maintenance Therapy
}

\author{
Seindy Arya Kusuma Timoer'1), Bhisma Murti²), RB Soemanto3) \\ ${ }^{1,2)}$ Masters Program in Public Health, Universitas Sebelas Maret \\ 3)Faculty of Social and Political Sciences, Universitas Sebelas Maret
}

\begin{abstract}
Background: Methadone maintenance therapy is one of substitution therapy is needed as a harm reduction approach of transmission of HIV/ AIDS through injecting drugs. To achieve the success of the therapy, therapy adherence is very important. This study was aimed to determine the factors affecting adherence methadone maintenance therapy using the approach of the Health Belief Model in clinical methadone maintenance therapy programs.

Subject and Methods: This was an analytical observation study with qualitative method, conducted in a community health center PTRM Manahan, Surakarta. A total of sample was selected with snowball. The data collected by using in-depth interviews, observation and document. The validity included triangulation of sources, methods, theory and study. The data analysis was using analytical models mating patterns, reduction, data presentation and analysis of data that form a pattern that can reveal the Health Believe Model or HBM linkage with therapy adherence.

Results: The results showed the factors of patients using the drug include family background, social environment, and knowledge. Factors underlying patients adhere to therapy, among others, those included in the high risk group of HIV / AIDS; the seriousness of the disease of HIV / AIDS; improved quality of life, side effects of methadone are more severe than injecting drug use; family and NGOs as a driving force to follow programs which is an instrument of HBM. Programs patient factors for non-compliant in following methadone maintenance therapy include patients still using drugs, objected to the levy on programs, and saturated with duration of therapy.

Conclusion: Methadone maintenance therapy adherence factors include the perception of vulnerability, perceived seriousness, benefits, barriers and trigger actions. Areas of compliance include methadone maintenance therapy patients were still using drugs, objected to the levy on programs, and saturated with duration of therapy.
\end{abstract}

Keywords: injecting drug users, HIV / AIDS, HBM, methadone maintenance therapy

\section{Corrrespondence:}

Seindy Arya Kusuma Timoer. Masters Program in Public Health, Sebelas Maret University, Jl. Ir. Sutami 36 A, Surakarta 57126, Central Java.

\section{BACKGROUND}

Injection Drug User's (IDU's) is one of the major risk factors for Human Immuno Deficiency Virus/ Acquired Immuno Deficiency Syndrome (HIV/ AIDS) transmission in recent years. World Health Organization (WHO) data shows that by the end of 2013, 35 million people have been infected by HIV/ AIDS in the world and still in the same year 2.1 million people were infected and 1.5 million died because of HIV/ AIDS (WHO, 2015).
The harm reduction program of injected drug transmission (harm reduction) is absolutely necessary. Methane Therapy is one of the substitution therapy needed as a harm reduction approach from HIV/ AIDS transmission through injecting drugs. PTRM is an activity of giving liquid methadone in oral dosage form (drunk), to the patient as an alternative opioid addiction therapy they used (National Narcotics Agency, 2013). 
Journal of Epidemiologi and Public Health (2017), 1(1): 49-56

https://doi.org/jepublichealth.2016.01.01.06

The addicts run this therapy type to escape from drug dependence, especially the type of heroin (putaw). The program purposeis to reduce the heroin use risk through injecting and improving quality of life, as well as increasing the confidence of addicts to change from user behavior at risk of being less risky or not at risk (Indonesia Republic Health Ministry, 2011).

According to the data in 2013 there are 83 methadone maintenance services in 16 provinces and 47 cities in Indonesia. Of these services have 2551 active patients. In Central Java there are 7 service places in 4 cities, and 2 service places are located in Surakarta, in Manahan Health Center and Dr. Moewardi (Indonesia Republic Health Ministry, 2014).

Data at the beginning of the second quarter of 2011 at Puskesmas Manahan had an active patient of 38 patients. HIV / AIDS progress report in the fourth quarter of 2015 decreased as many as 13 active patients reaching the PTRM clinic therapy service of Puskesmas Manahan Surakarta.

National Consensus Development Panel (1998) notes that treatment duration and continuity is an important factor in methadone treatment effectiveness. This report provides information on facility's policy on withdrawal from methadone (Indonesia Republic Health Ministry, 2007).

Factors not affecting treatment compliance include age, sex, HIV / AIDS status, education level, knowledge level, distance from service, drug side effects, employment status, health care services (Risnawati, 2013; Rodiyah, 2011).

HBM is one of the models used to explain changes in health behavior. This model states that health behavior will be influenced by factors, including perceived susceptibility perceptions, perceived seriousness perceptions, benefit and barrier perceptions to perceived benefits and barriers, and cues to action) (Mabachi, 2008; Safri FM, 2013).

Based on the phenomenon, the researcher wanted to study the factors that influence the adherence of methadone maintenance therapy by using HBM approach in clinic of PTRM Puskesmas Manahan Surakarta.

\section{SUBJECT AND METHODS}

This was an analytic study with qualitative approach. Study subjects in this study were patients with Methadone Treatment Therapy at Clinic PTRM Puskesmas Manahan Surakarta. Sampling technique in this study was theoretical sampling. Specific sampling techniques were used in this study to reveal social phenomena occurring in populations that had a network but difficult to access (Murti, 2013).

The informants used in this study were 4 patients, a nurse, and a pharmacist at the PTRM clinic of Manahan community helath center, Surakarta as well as a Member of Mitra Alam National Non-Governmental Organization as Peer Support Group for Methadone Maintenance Therapy patients.

Data analysis used in this study was pattern matchmaking analysis. According to Yin (2008) the pattern match making analysis was to compare patterns based on empirical data with predicted patterns.

\section{RESULT}

Some main factors on patients using drugs included knowledge factors, family background, and social environment. In knowledge background, it was obtained informants less knew about what the drug was. They only knew that drugs were illegal drugs and could not be traded freely. According to informants they were not equipped and rarely knew what drug was. 
Even if they had been informed by health workers and non-governmental organizations, they still could not understand them enough to cause wrong perceptions. This was in line with the following informants:

"What does it stand for? Well I do not know, I only know that it is a restricted drugs. "(Informant 1)

In family background, it was obtained that informants used drugs as an escape from various problems of life faced. This was in line with the following informants:

"He said that it was only an escape every time I asked for." (Informant 4).

Table 1. Informant distribution based on parents' marital status

\begin{tabular}{lcc}
\hline $\begin{array}{c}\text { Marital } \\
\text { Status }\end{array}$ & Number & Percentage \\
\hline Merried & 8 orang & $61.5 \%$ \\
divorce & 5 orang & $38.5 \%$ \\
\hline
\end{tabular}

Based on Table 1 showed that informants whose marriage status was married parents were 8 people (61.5\%), and informants whose marriage status was divorced parents were 5 people (38.5\%).

Based on social background, it was found that the informant admitted the first time using drugs since they were teenagers. They had a reason for being offered first by friends who had used drugs before. This was possible because of free and wrong association in choosing friends. This was in line with the following informants:

"Formerly, it was because of a friend's offer, he said that it was delicious." (Informant 3).

PTRM Compliance Rate.

Table 2 Informant distribution based on treatment adherence

\begin{tabular}{lll}
\hline \multicolumn{1}{c}{ Category } & Number & Percentage \\
\hline Obey & 6 orang & $46.1 \%$ \\
Disobey & 7 orang & $53.9 \%$ \\
\hline
\end{tabular}

From Table 2 above, there were 6 respondents (46.1\%), and non-adherent informants for therapy (53.9\%).

Patient'sfactors to follow the therapy, among others, were included in the high risk group of HIV/ AIDS transmission (perceived susceptibility); seriousness about HIV/ AIDS (perceived seriousness); increased quality of life (perceived benefit); more severe side effects of methadone from perceived barrier; families and NGOs as a driver to follow PTRM (cues to action)

In some factors which belonged to high risk groups of HIV / AIDS (perceived susceptibility) the informant was well aware of injecting usedangers. Informants were also aware that as IDUs had a high risk of HIV/ AIDS transmission. With sufficient understanding, IDUs were trying to reduce the harmful effects of injecting drug use. Although having been done, they were still aware of the chances of contracting the disease. This was in line with the following informants:

"We feel, depending on us how to use a syringe. One needle syringe for one person, not used as one for all in order not to be infected." (Informant 2)

On the seriousness factor of HIV/ AIDS (perceived seriousness), the informant was aware of the harmful effects of injecting drug abuse. To know if there was the disease or not, the informants do the VCT examination, as disclosed by the informant as follows:

"Ever, I did the first VCT here." (Informant 1).

But different things were revealed when some informants did not conduct inspection in fear of the examination results. This is as revealed by the informant as follows:

"Never, how come because I'm afraid of the same result." (Informant 3 ) 
Journal of Epidemiologi and Public Health (2017), 1(1): 49-56

https://doi.org/jepublichealth.2016.01.01.06

In addition to reducing or preventing the occurrence of the disease sometimes they use a sterile needle and do not switch syringe with another when using injecting drugs. This is to reduce contact with other IDUs so as to reduce the risk of adverse effects of drugs. This is in line with the following informants:

"One needle syringe for one person, not used for sharing in order not to be infected." (Informant 2)

On the perceived benefits of Methadone Therapy services, the informant supported with PTRM. Because of with this service, it made them have more hope to obtain out of dependence injecting drug. The benefits experienced after methadone therapy. With the methadone therapy program, informants felt that they had a better quality of life than before. This was in line with the following informants:

"Yes, I support it, it can eliminate its desire to consume putaw, switching from the syringe to oral makes us more secure, the focus of his life is more organized. It is better now than long ago. Now we can work regularly, if at first we only played on. Life quality is better. "(Informant 1)

In the perceived barriers of Methadone Maintenance Therapy services, the informant felt the side effects if not taking methadone even once. Patients sometimes experienced it within a period of about a month even that he felt that it could be worse than on the sakaw that caused putaw. And the informant could only "tide the body" or just wait until the side effects subsided. And consider these side effects as a consequence of their non-adherence therapy. This is in line with the following informants:

"I know, the effect is the same assakaw. If you do not drink once, all your bodies will be sick. But the pain is worse than putaw. Because consumingputaw a week, we are healed, if this is up to a month. If you are abused, just put your body." (Informant 1).

Cues-to-action factors in patients following Methadone Maintenance Therapy services, informants considered that the families were factors that encouraged them to follow Methadone Maintenance Therapy. In addition, the desire to heal from within themselves makes its own spirit in obeying therapy. Informants obtained information about this therapy from non-governmental organizations. Media information provided sometimes through counseling or meetings that have been scheduled. This is in line with the following informants:

"Family and willingness to recover from dependence make me join this therapy".(Informant 2).

PTRM patients' factors for noncompliance with methadone maintenance therapy include patients, still using drugs, felt objection to retribution to PTRM, and saturation with therapy length.

On factors concerning patients still using drugs, the informants assessed the cause of Methadone's non-adherence therapy were the patients still using the drug. So, when using drugs, sometimes patients Methadone Maintenance Therapy forgot that they were on process of therapy. This was in line with the following informants:

"Not burdensome, just 7500 but depends on the individual as well". (Informant 1).

In the case of objection to retribution to PTRM, the informant assessed the cause of non-adherence Methadone Maintenance Therapy was severe with the existing retribution in therapy. Since January 2016, patients of Methadone Therapy Program who used PKMS facility no longer can use because the facility has been revoked. This was in line with the following informants: 
"This disobedience because the heroin addicts are multidrug which means also use other drugs besides heroin for example; marijuana and benzodiazepin group as well. So this disobedience is usually mixed with other drugs, the second in the puskesmas itself is 7500 distribution, so they object to the distribution. Sometimes they are bored due to methadone every day so, they sometimes come together. And the most dominant is disobedience. "(Informant 6)

But a difference was revealed when some informants considered the reason for a very illogical distribution in nonadherence therapy. Because when he consumed putaw, it will cost more expensive. This is in line with the following informants:

"Yes, they usually disobey because they are still mixing, then the number of distributors is still wandering to offer, they are sometimes bored because of treatment and hearing about revoking PKMS so they are away from therapy."(Informant 7).

Background of saturation was the length of therapy according to informant long-term use of methadone and had to be done every day resulted in increased saturation levels for patients Methadone Maintenance Treatment.

"Lately, mostly because of objections to the retribution after PKMS revoked so many dropped out, but previously they are saturated so sometimes there are still consuming."(Informant 5).

\section{DISCUSSION}

Increasing the number of patients dropping out year by year in PTRM Clinic Puskesmas Manahan Surakarta indicates high noncompliance rate and low compliance rate of Methadone Therapy Patient. Health trust assessment or HBM model as the underlying factor for patients adhering to or not following therapy include those in the high risk group of HIV/ AIDS transmission (perceived susceptibility); seriousness about HIV/ AIDS (perceived seriousness); increased quality of life (perceived benefit); more severe side effects of methadone from perceived barrier use; families and NGOs as a driver to follow PTRM (cues to action).

High risk group of HIV/ AIDS transmission (perceived susceptibility).

Understanding the perception of susceptibility to HIV/ AIDS, informants realized that as IDUs had a high risk of HIV / AIDS transmission. This was due to the behavior of the use of non-sterile needles and alternate with others. This behavior led to an increase in the number of HIV / AIDS cases.

The harm reduction behavior of informants was done by using needle syringes that did not change with other users. Transmission usually occurs due to the use of syringes simultaneously. In addition, harm reduction was done by switching to methadone as a replacement therapy.

The study results are in line with the theory of HBM (Rosenstock, 1982), which states that a person has perceived susceptibility which means that those who feel can obtain the disease will be more quickly feel threatened. A person will act to prevent a disease if he feels that it is really possible to obtain the disease. The perceived susceptibility of each individual differs depending on the perception of the risks facing the individual in a given situation (Frances, 2005).

\section{Seriousness about HIV / AIDS (per- ceived seriousness).}

The informant understands the seriousness of the disease that will be transmitted so some people are aware of the importance of the examination. Health 
examination to see the adverse effects of HIV/ AIDS transmission used VCT.

But for some patients Methadone Maintenance Therapy is still reluctant in conducting VCT examinations. This is done because they are afraid of results that may not fit what they imagine.

The study results are in line with the theory of HBM (Rosenstock, 1982). This theory explains that in taking preventive action and treatment influenced by perceived severity is the severity perception that may be felt when suffering from a disease. One's severity perception of illness will be suffered. This view encourages a person to seek treatment and prevention of the disease. This seriousness is coupled with the consequences of a disease such as death, physical and mental functioning reduction, disability and its impact on social life.

\section{Perceived benefits or benefits of the recommended action.}

Informants can experience significant benefits of methadone therapy after they have been on therapy for a long time and regularly. This can be seen from the increasing patient's life quality for PTRM patients.

The results of this study indicate that individuals consider the benefits of behavioral changes undertaken in reducing the disease threat. This perception is also related to the availability of resources, so this action arises. This perception is influenced by the norms and group pressures. This is in line with the theory that states in the prevention and treatment will be influenced by perceived benefits (perceptions about the benefits when doing action) (Kirakoya, 2013).

Perceived barriers or obstacles from recommended actions.

Side effects of Methadone Maintenance Therapy felt by the patient is like sakawbeside the body becomes ill. It takes effort in eliminating side effects, such as; some patients do not do anything, other patients buy drugs from stalls to reduce the pain that he suffered, and there are patients who use drugs again.

The study results indicate that side effects may support or inhibit adherence to the therapy. This is in line with study results by Rodiyah (2011), which indicate that drug side effects do not affect compliance Methadone Maintenance Therapy.

When the informant in his therapy still uses injecting drugs, the patient will forget the therapy he has undergone. This can happen when the effects of injecting drugs that the patient feels are causing the patient not to want to access PTRM. In addition, the use of long-term methadone for a long time and done every day cause increasing saturation levels for PTRM patients. This if not resolved will result in the patient being discouraged in following PTRM.

Some of the PTRM patients who object to the withdrawal of the PKMS facility are still trying to access PTRM services. Patient seriousness is appreciated by the provider by the way the patient can be indebted when using PTRM services. But this creates a new problem for the provider when the patient accumulates a lot of debt and cannot pay it, so with a little force the provider drops out of the patient PTRM.

Thestudy results are in line with the theory of Ying Wang (2011) which states that in doing the prevention and treatment of HIV / AIDS influenced by perceived cost is a perception of the cost / negative aspects that prevent individuals to perform health measures including in methadone maintenance therapy, such as expensive, danger, unpleasant experience, pain, time providing, far place, fear and embarrassment 
with health workers, long and complicated procedures (informative consent).

\section{Cause to action factor}

Information mediaabout Methadone Maintenance Therapy in this study obtained patients from non-governmental organizations. So that with media access information they use to improve knowledge about Methadone Maintenance Therapy.

The reasons of selecting Methadone Maintenance Therapy include the reduction of the harmful effects of injecting drug use, assuming that methadone maintenance therapy is the only treatment to treat dependency of putaw usage, and solicitation by Non Governmental Organizations (NGOs).

The supporting factor of Methadone Maintenance Therapy for the PTRM patient is family support playing an important role in following the therapy. This happens because family support stimulates the patient to recover quickly. NGOs also play a role in attracting PTRM patients for therapy. In addition, when the stimulation is reduced, the role of health workers in PTRM to provide counseling can increase the desire to heal.

The study results are in line with the theory of HBM (Rosenstock, 1982), the trigger factor to act comes from themselves and others. Motivation to heal is also a trigger factor coming from themselves. Other factors come from families, NGOs and health workers at PTRM. Rodiyah (2011) suggests that motivation, peer support, and family support may influence Methadone Maintenance Therapy compliance.

\section{REFERENCES}

Badan Narkotik Nasional(2013). Pendampingan Pasca rehabilitasi di PTRM Bogor Timur. Diakses dari http://- www.bnn.go.id/read/berita/10867/bl og-single .html.

Direktorat Bina Pelayanan Medik Spesialistik Pusat Pandidikan dan Pelatihan Kesehatan (2007). Modul dan Kurikulum Pelatihan Program Terapi Rumatan Metadon (PTRM). Jakarta: Departemen Kesehatan Republik Indonesia.

Kirakoya F(2013). Voluntary HIV testing and risk sexual behaviour among health care workers: a survey in rural and urban Burkina Faso. BMC Public Healt.13:540.

FrancesM, Shaver (2005). Sex Workers Study, Metodological and Ethical Challanges.Journal of Interpersonal Violence. 20(2):296- 319.

Janz NK, Becker MH (1984). The Health Belief Models: A dekade Letter. Health Education Quartely.

Kementerian Kesehatan Republik Indonesia (2011). Laporan Triwulan Situasi Perkembangan HIV/AIDS di Indonesia sampai dengan 30 September 2010. Jakarta.

(2014). Buletin Jendela Data dan Informasi Kesehatan: Gambaran umum penyalahgunaan narkoba di Indonesia. Jakarta.

KomisiPenanggulangan AIDS (KPA). (2015). Kondisi HIV \& AIDS di Jawa Tengah.

Mabachi MN (2008). HIV/AIDS in Africa a Discoursive Perspective. Unpublised Master's Thesis. Kansas: University of Kansas USA.

Murti B (2013). Desain dan Ukuran Sampel Untuk Penelitian Kuantitatif dan Kualitatif di Bidang Kesehatan. Yogyakarta: Gajah Mada University Press.

Risnawati AD (2013). Pengaruh Karakteristik Terhadap Terbentuknya Perilaku Peserta Terapi Rumatan Metadon 
Journal of Epidemiologi and Public Health (2017), 1(1): 49-56

https://doi.org/jepublichealth.2016.01.01.06

(TRM) di Klinik Rumatan Metadon Puskesmas Manahan Surakarta.

Rodiyah K (2011). Analisis Faktor yang Berhubungan Dengan Kepatuhan Berobat Terapi Rumatan Metadon pada Pengguna Napza Suntik (Penasun) (Studi di Puskesmas Manahan Kota Surakarta Tahun 2011).

Safri FM, Sukartini T, Ulfiana E (2013). Analisis Faktor yang Berhubungan dengan Kepatuhan Minum Obat Pasien TB Baru Berdasarkan Health Belief Models di Wilayah Kerja Pus- kesmas Umbulsari, Kabupaten Jember. Jurnal Universitas Airlangga: 110.

Spire B, Lucas GM, Carrieri MP (2007). Adherence to HIV treatment among IDUs and the role ofopioid substitution treatment (OST). International Journal of Drug Policy 18:262-270.

Wang Y (2011). Factors Assosiated with Utilization of a Free HIV VCT Clinic by Female Sex Worksers in Jinan City, Northern China. Aid Behaviour. 15: 702-71. 